NBER WORKING PAPER SERIES

THE ROLE OF FINANCIAL POLICY

Roger Farmer

Working Paper 24498

http://www.nber.org/papers/w24498

\author{
NATIONAL BUREAU OF ECONOMIC RESEARCH \\ 1050 Massachusetts Avenue \\ Cambridge, MA 02138 \\ April 2018
}

This paper was written for a special edition of the Review of Keynesian Economics to commemorate the 50th anniversary of the publication of Milton Friedman's 1968 Presidential Address to the American Economic Association. I wish to thank Matías Vernengo for encouraging me to write an essay on this topic and C. Roxanne Farmer for her editorial assistance. The views expressed herein are those of the author and do not necessarily reflect the views of the National Bureau of Economic Research.

NBER working papers are circulated for discussion and comment purposes. They have not been peer-reviewed or been subject to the review by the NBER Board of Directors that accompanies official NBER publications.

(C) 2018 by Roger Farmer. All rights reserved. Short sections of text, not to exceed two paragraphs, may be quoted without explicit permission provided that full credit, including () notice, is given to the source. 
The Role of Financial Policy

Roger Farmer

NBER Working Paper No. 24498

April 2018

JEL No. E3,E4

\begin{abstract}
I review the contribution and influence of Milton Friedman's 1968 presidential address to the American Economic Association. I argue that Friedman's influence on the practice of central banking was profound and that his argument in favour of monetary rules was responsible for thirty years of low and stable inflation in the period from 1979 through 2009. I present a critique of Friedman's position that market-economies are self-stabilizing, and I describe an alternative reconciliation of Keynesian economics with Walrasian general equilibrium theory from that which is widely accepted today by most neo-classical economists.
\end{abstract}

Roger Farmer

UCLA

Department of Economics

Box 951477

Los Angeles, CA 90095-1477

and CEPR

and also NBER

rfarmer@econ.ucla.edu 
Friends, Romans, countrymen, lend me your ears;

I come to bury Caesar, not to praise him.

The evil that men do lives after them;

The good is oft interred with their bones;

So let it be with Caesar.

(William Shakespeare, Julius Caesar)

Opening an essay to honour the work of a great man by quoting from Marc Anthony's words at Julius Caesar's funeral, may appear to some to be a boorish opening gambit. But I do not mean disrespect. Milton Friedman was one of the greatest economists, if not the greatest economist, of the twentieth century. Friedman's views of the appropriate role of monetary policy have become accepted wisdom and they form the core belief of every practicing central banker in the world today. That does not make them right. I come to bury some, but not all, of Friedman's ideas. And as for Friedman himself, unlike Marc Anthony, I come to praise him.

In this anniversary year, a great deal has been said about the importance and influence of Friedman's 1968 presidential address to the American Economic Association. I will not try to duplicate the excellent essays that have appeared elsewhere. Instead, I will explain what, in my opinion, is the core content of "The Role of Monetary Policy" and I will outline how Friedman's key arguments have shaped the development of modern macroeconomic theory. ${ }^{2}$

It will not have escaped the astute reader that I have borrowed from and adapted Friedman's title in choosing to name my own contribution. Central banks, from the inception of central banking in seventeenth century Europe, have been charged with two responsibilities: Price stability and financial stability. By focusing on the role of financial stability, as opposed to price stability, I will provide a framework in which we may think about the design of a complementary institution to the modern central bank. Whereas the central bank is charged with price stability, my complementary institution would be charged with financial stability.

Milton Friedman was the greatest monetary theorist of his generation: His work laid the foundation for the day-to-day operation of monetary policy as it is perceived today by academic economists and central bankers alike. The institution of the modern central bank owes a great deal to Milton Friedman and the success of central banks in alleviating the worst effects of the 2008 financial crisis are due largely to the fact that modern central bank economists studied Friedman's work.

My goal in this essay is to build on the foundation that Friedman laid in his 1968 presidential address by extending some of his arguments and rebutting others. The praise that I promised in my opening paragraph is for the success of a rules-based monetary policy which, in my opinion, was responsible for more than twenty-five years of economic stability from 1980 to 2007, a period aptly named, the Great Moderation. The criticism implicit in my announced intent to 'bury Friedman', is for the theme which pervades all of Friedman's writing, that the economy is a self-stabilizing system that, if left to itself, will achieve an efficient outcome.

Milton Friedman was the initiator of the resurgence of the Quantity Theory of Money, but the North American Keynesians, predominantly based at MIT, Harvard and Yale, were complicit

\footnotetext{
2 Ironically, the approach that is today labelled as "New-Keynesian economics" is much closer to Friedman's views than to anything that would be recognized as Keynesian by Keynes or by his contemporaries. And for a verbal summary of the central thesis of modern NewKeynesian economics you could not do better than to absorb the key thesis of David Hume's essay, Of Money, written in 1742.
} 
in its acceptance. ${ }^{3}$ In modern interpretations of macroeconomics, Keynesian economics is a wrinkle on the Quantity Theory that explains why unemployment may be temporarily high as the economy responds to an unforeseen monetary shock. It is that idea which I come to bury; not the man who was responsible for its twentieth century resurgence.

\section{The Monetary History of the United States}

Friedman, writing in 1968, was an observer of what he perceived to be the failure of activist monetary policy. In the period from 1942 to 1950 the Fed had followed a policy of maintaining an interest rate on short-term debt of $3 / 8$ percent on treasury bills and of placing a ceiling on long-term government bonds of $2 \frac{1}{2}$ percent. The purpose of this policy was to enable the government to finance the war cheaply. ${ }^{4}$

The policy of maintaining a low interest rate led to a conflict between the Treasury Secretary, John Wesley Snyder, and the then president of the New York Fed, Allan Sproul. ${ }^{5}$ Sproul was concerned that the Korean War, which broke out in the Spring of 1950, would lead to inflation and he argued for an interest rate rise that, if enacted, would have led to the long-term bond rate breaching the $2 \frac{1}{2}$ percent ceiling. The conflict between the Treasury and the Fed was resolved in 1951 when the Fed was granted independence in an historic agreement known as the Accord.

Friedman's 1968 address provided economic analysis to explain why there was a conflict between Treasury and Fed objectives. His argument was based on three propositions. The first, he borrowed from Knut Wicksell who argued in his 1898 work Interest and Prices, that there is an underlying natural rate of interest, determined by the willingness of people to save and the propensity of firms to invest. The second was Friedman's revival of the Quantity Theory of Money which he formulated as the proposition that money income bears a stable relationship to the quantity of money. The third was new to Friedman's presidential address. Just as there is a natural rate of interest so, Friedman argued, there is a natural rate of unemployment.

\section{The Natural Rate of Interest}

The natural rate of interest is a number that I will denote by the symbol $r$. It denotes the premium that people require willingly to exchange a promise to deliver a standard bundle of commodities in the future for a standard bundle of commodities today. $r$ is determined by the underlying features of the economy. These include the state of technology, the population growth rate, and the preferences and endowments of the people.

The money rate of interest is a number that I will denote by the symbol $i$. It denotes the premium that people require willingly to exchange a promise to deliver money in the future for money today. $i$ is chosen by the central bank which, in a modern economy, is the monopoly supplier of money. The only constraint on the money rate of interest is that it

\footnotetext{
${ }^{3}$ I learned the term North-American Keynesians, from David Laidler who used it in his graduate lectures at the University of Western Ontario to differentiate the position taken by Paul Samuelson, Robert Solow and James Tobin in North America, from that of Joan Robinson in Cambridge England. Robinson and her contemporaries in Cambridge England never accepted the North American view that Keynesian economics was about sticky prices.

${ }^{4}$ Robert Hetzel and Ralph Leach (2001).

${ }^{5}$ Monetary policy, then as now, was set by the Federal Open Market Committee (FOMC). Sproul was the dominant figure on the FOMC and it was Sproul who brought the conflict between the FOMC and the Treasury to a head (Hetzel and Leach op cit).
} 
cannot move far below zero and until recently, most economists considered zero itself to be the lower bound.

The natural rate of interest is connected to the money rate of interest by the fact that a bundle of commodities can be exchanged for money in the present for an average price that I will denote by the symbol $p$. And a bundle of commodities can be exchanged for money in the future for at an average price that I will denote by the symbol $p^{\prime}$. If we use the symbol $\Delta x$ to denote the proportional change of a variable $x$, between the present and the future, it follows from the idea that borrowing or lending in real terms must have the same price as borrowing or lending in money terms that,

$$
\text { (1) } r+\Delta p=i \text {. }
$$

This equation, sometimes referred to as the Fisher equation after the American economist Irving Fisher, states that the natural rate of interest, $r$, plus the rate of inflation, $\Delta p$, is equal to the money rate of interest, $i$.

\section{The Stable Velocity Assumption}

Friedman's analysis of post-WWII monetary policy was based on the implications of his magisterial study of American monetary history which had convinced him that in a century of US data there was a stable relationship between the velocity of circulation and the rate of interest. ${ }^{6}$ The velocity of circulation is the ratio of the dollar value of GDP to the dollar value

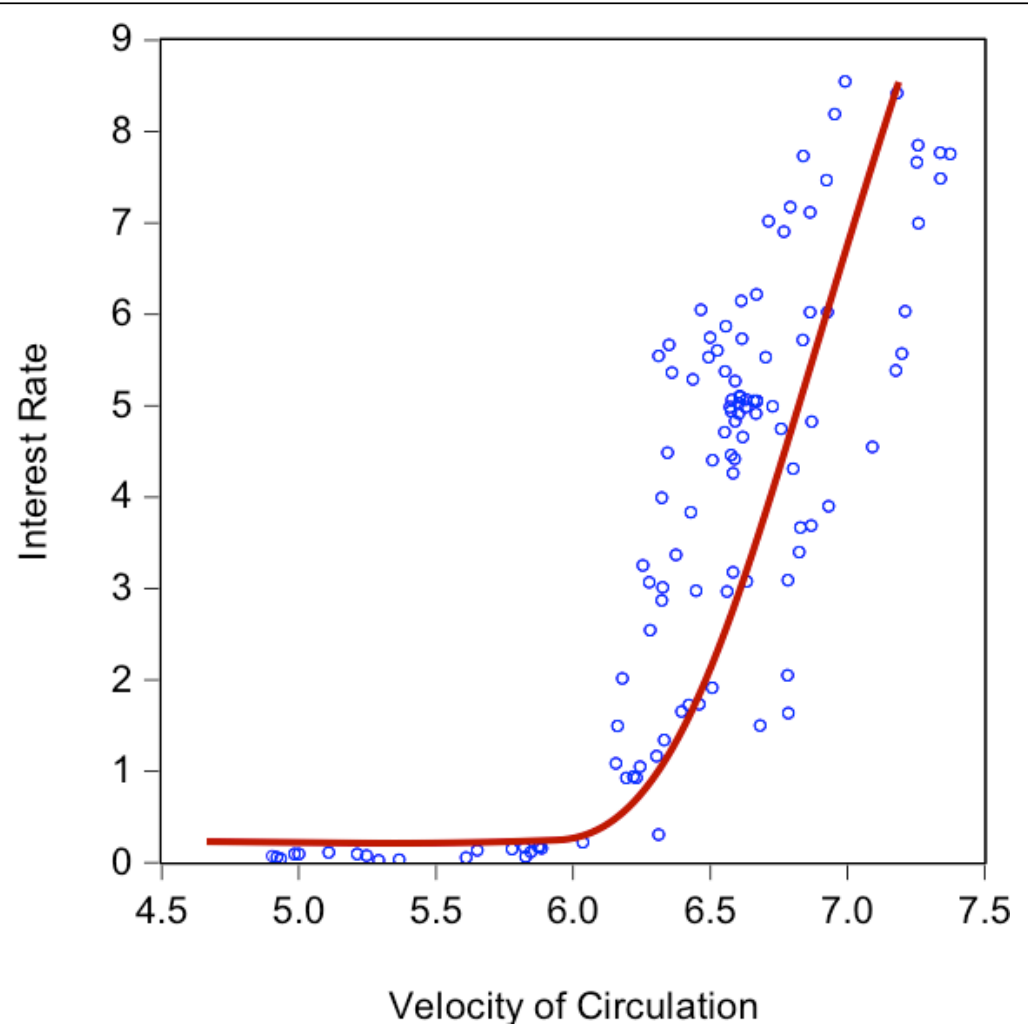

Figure 1: Velocity and the Interest Rate in the US Data from 1985 through 2017

${ }^{6}$ Friedman and Schwartz, 1963. 
of the stock of money. Crude statements of the Quantity Theory of Money state that this ratio is constant. Friedman provided a more refined statement of the Quantity Theory of Money in which the velocity of circulation is a stable function of the money rate of interest.

In Figure 1 I have plotted some evidence in support of Friedman's restatement of the Quantity Theory of Money. The vertical axis of Figure 1 plots the three-month treasury bill rate and the horizontal axis plots the velocity of circulation. ${ }^{7}$ It is clear from this figure that there is an approximately linear relationship between these two variables when the interest rate is positive. This relationship breaks down when the interest rate is zero, a fact that has important consequences for the ability of central banks to control inflation when the money rate of interest is zero.

If we use the symbol $y$ to mean the real value of a basket of all of the goods produced in a given year, and the symbol $M$ for the quantity of money, the velocity of circulation is defined to be the ratio of the money value of GDP, this is $p \times y$, to the dollar value of the stock of money, this is $M$. Using $v$ for the velocity of circulation,

$$
\frac{(p \times y)}{M}=v(i)
$$

The symbol $i$ in parentheses denotes the idea that $v$ is a function of $i$; that is, for every positive value of the money rate of interest, $i$, there is a different value of the velocity of circulation, $v$. The evidence for the assumption that there is a stable relationship between the money value of GDP and the quantity of money is presented in Figure 1.

To connect equations (1) and (2) it helps to express the velocity equation in terms of proportional changes. For any situation in which the interest rate is held constant, this equation implies the following connection between inflation, $\Delta p$, money growth, $\Delta m$, and the growth of real GDP $\Delta y$,

$$
\text { (2a) } \Delta p=\Delta m-\Delta y \text {. }
$$

Equation ( $2 a$ ) follows from the fact that if the velocity of circulation is constant, as it is whenever the interest rate is unchanging, the numerator of the left-hand-side of Equation (2) must grow at the same rate as the denominator. We arrive at the proposition that inflation is equal to the rate of money creation minus the economy's real growth rate.

Friedman assumed, as did Wicksell, that the natural rate of interest is determined by factors outside of the control of the government. Hence the use of the term 'natural'. He added a new element to Wicksell's analysis: The unemployment rate gravitates to a 'natural rate of unemployment'.

The Natural Rate of Unemployment

In Wicksell's analysis, if people borrow and lend feely in loan markets, the price of a loan will settle on a number; he called this the natural rate of interest. In Friedman's analysis, a similar concept applies to the labour market. If firms and workers trade labour services freely in

${ }^{7}$ The figure plots the ratio of quarterly GDP to Divisia M1. All data are from 1985Q1 through 2013Q4. Source: FRED II, federal Reserve Bank of St. Louis. 
labour markets, the unemployment rate will settle on a number: He called this the natural rate of unemployment.

When the unemployment rate is equal to the natural rate of unemployment, the real value of all of the incomes earned by the factors of production, land, labour and capital, attains a value referred to as 'potential real GDP'. Potential real GDP increases over time as the number of people increases, as we build additional factories and machines and as society discovers better techniques for producing additional commodities using the same quantities of land, labour and capital.

If we use the symbol $\bar{y}$ to mean potential real GDP, Friedman's third proposition is that the economy is never far from a position in which $y=\bar{y}$. If we assume, as did Friedman, that potential GDP grows at a rate, $g$, beyond the reach of fiscal or monetary policies, it is a shortstep to the proposition that

$$
\Delta y=g
$$

Putting this together with the Fisher Equation and the velocity equation we arrive at the following two-equation representation of Friedman's system,

$$
\begin{gathered}
r+\Delta p=i, \\
\Delta p+g=\Delta m .
\end{gathered}
$$

Equations (1) and (2b) represent constraints on monetary policy that hold in a long-run stationary state and, seen in that light, they are identities that no economist, whether they are in favour or opposed to activist fiscal and monetary policies, would dispute. In the following section, I will use these equations to explain the conflict that arose between the Treasury Secretary, John Wesley Snider and the President of the New York Federal Reserve Bank, Alan Sproul, in 1951. My explanation is based on the fact that the Treasury and the FOMC cannot independently choose the rate of growth of dollar denominated liabilities.

Then I will turn to a more controversial component of Friedman's presidential address. I will dispute his argument that the Federal Reserve Bank should not attempt to influence the level of economic activity either in the short-run or in the long-run. I will argue that the distinction between the short-run and the long-run that was accepted in the 1960s, by monetarist and Keynesian economists alike, is a false dichotomy based on a flawed interpretation of Keynes' general theory.

\section{Long-run constraints on monetary policy}

It might appear from inspecting equations (1) and (2b) that Friedman should not have been disturbed by the Post WWII policy in which the Federal Reserve Board was charged with maintaining an interest rate of $3 / 8$ percent on treasury bills and of placing a ceiling on longterm government bonds of $21 / 2$ percent. By maintaining an interest rate of $3 / 8$ percent on treasury bills, Equation (1) implies that the inflation rate will be kept low and equal to the difference of the money interest rate of $3 / 8$ percent and the natural interest, $r$. But this argument misses the mechanism by which the Federal Reserve Board maintains any given treasury-bill rate.

To keep the interest rate on treasury bills at $3 / 8$ percent, the Federal Reserve Board must stand ready to buy or sell as many of these bills as required to keep their price consistent with 
a 3/8 percent annual return. Federal Reserve Bank purchases of assets are accompanied by offsetting creation of Federal Reserve Bank liabilities which are the base on which all other forms of money are created. It follows that an expansion of Fed liabilities leads inexorably to an increase in the quantity of money.

If the treasury prints dollar-denominated interest-bearing liabilities at an increasing rate, as it began to do in 1951, the FOMC must purchase most or all of those interest-bearing liabilities. If it did not, the Treasury would be forced to increase the yield on three-month treasury bills to persuade the private sector to hold them. When the Treasury is issuing large and increasing numbers of dollar-denominated securities, maintaining a low money rate of interest implies that the money supply growth rate must be high and increasing. Equations (1) and (2b) then provide two different and inconsistent explanations for the determination of the inflation rate that cannot both hold at the same time.

In 1951, when Alan Sproul went head to head with John Wesley Snider, the Fed already owned almost all of the treasury bills in existence. ${ }^{8}$ The Korean War was financed by a big expansion in government bond issues. If the Federal Reserve had continued to try to hold down the interest rate on three-month treasury bills at $3 / 8$ percent, it would have led to excessive growth in the money supply. Excessive money supply growth would have caused an expectation on the part of the public that inflation would increase in the future and that increase in expected inflation would have led the public to demand an interest rate in excess of $2 \frac{1}{2}$ percent to hold long bonds. Friedman's presidential address, in which he explained this argument, was a triumph of clear thinking over the contemporary view of some Keynesian economists, predominantly based in the UK, who clung to cost-push theories of inflation which ignored the role of money. ${ }^{9}$

\section{Short-run constraints on monetary policy}

Writing in 1968, Friedman had already won a major battle in his dispute with Keynesian economists. Keynes argued in The General Theory that free-market capitalist economies will frequently become stuck in a long-run equilibrium position with underemployment of resources: He coined the term 'involuntary unemployment' to describe that situation. For Keynes, involuntary unemployment was not a temporary situation that can be corrected by flexible wages and prices. It was a permanent rest-point of a free-market system.

By introducing the concept of the natural rate of unemployment Friedman provided a very different theory of employment from that advanced by Keynes. Initially, protagonists on both sides of the debate accepted that market economies might get stuck in a 'liquidity trap' in which flexible wages and prices were incapable of restoring full employment equilibrium. That idea was laid to rest by Patinkin, in his seminal work, Money Interest and Prices (Patinkin 1956). The following quote from Friedman uses Patinkin's argument, that aggregate demand depends on aggregate wealth, triumphantly to bury the Keynesian position.

"These theoretical developments [wealth effects on aggregate demand] did not undermine Keynes' argument against the potency of orthodox monetary measures when liquidity preference is absolute since under such circumstances the

\footnotetext{
${ }^{8}$ Hetzel and Leach (2001)

${ }^{9}$ The idea that the inflation rate is independent of the money supply, a widely held position in the 1950s, was articulated in the report of the Radcliffe Commission (1959)
} 
usual monetary operations involve simply substituting money for other assets without changing total wealth. But they did show how changes in the quantity of money produced in other ways could affect total spending even under such circumstances. And, more fundamentally, they did undermine Keynes' key theoretical proposition, namely, that even in a world of flexible prices, a position of equilibrium at full employment might not exist. Henceforth, unemployment had again to be explained by rigidities or imperfections, not as the natural outcome of a fully operative market process." (Friedman 1968 pages 2-3, my emphasis)

In the 1960s, the debate between monetarists and Keynesians was couched in terms of the IS-LM diagram, reproduced in Figure 2. The intersection of the downward sloping line labelled the IS Curve, and the upwards sloping curve labelled the LM curve, represents a rest position of the system. Keynes argued that there might be multiple such positions, each associated with a different IS curve, almost all of which would be associated with underemployment of resources.

If the economy were to be stuck in a 'liquidity trap', a fall in wages and prices that shifts the LM curve to the right would be incapable of restoring full employment. Patinkin pointed to a different mechanism whereby flexible wages and prices could restore full employment equilibrium. He argued that a fall in money prices would cause a rightward shift of the IS curve by increasing the real of the wealth of households as the purchasing power of their nominal assets would be greater if prices and wages were to fall.

Once they accepted Friedman's argument, the North American Keynesians became monetarists in all but name. Keynesians and monetarists each agreed that, left to itself, a capitalist economy will eventually restore full employment as money wages and money prices

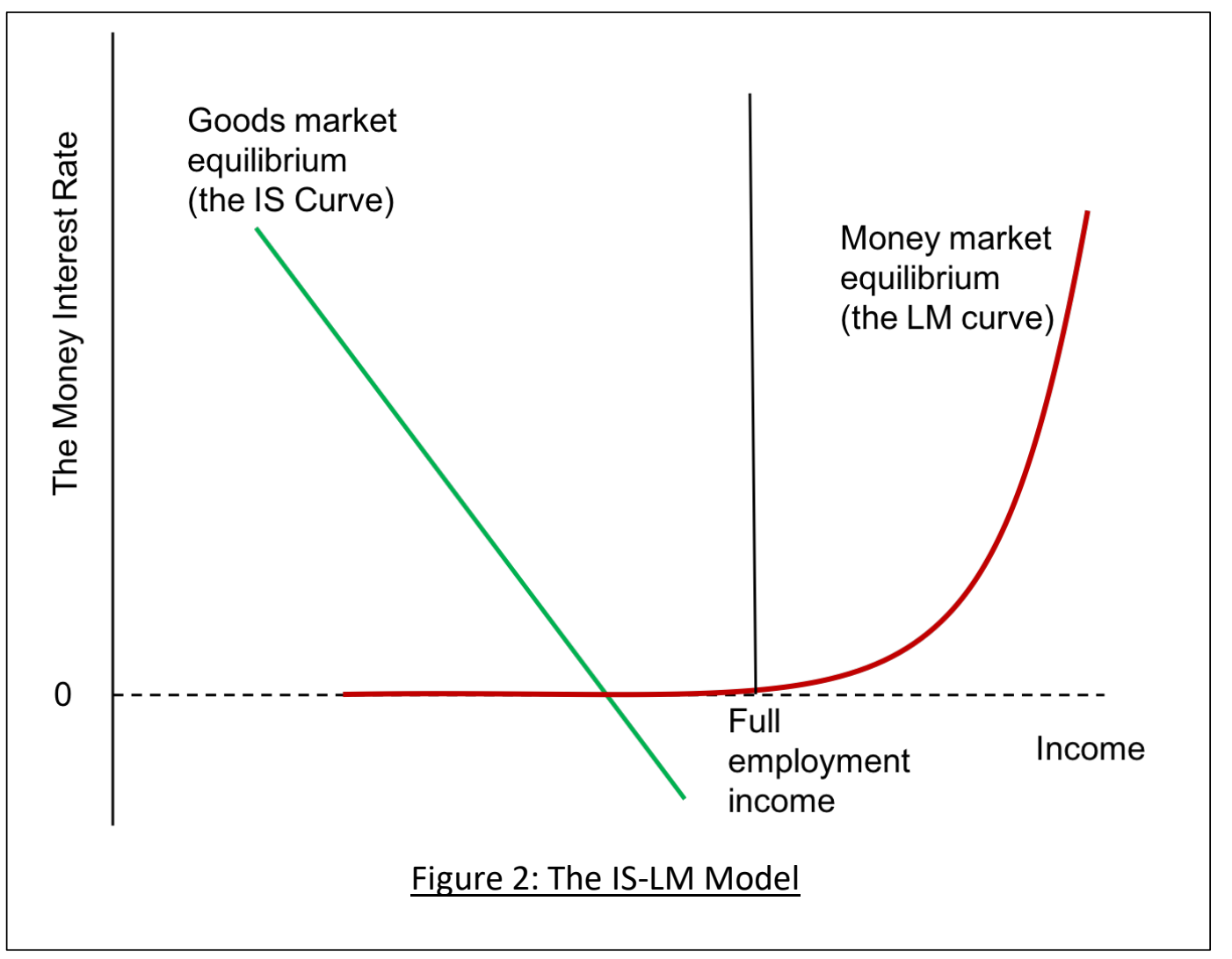


adjust to clear all markets. The debate was no longer about whether a free-market economy with flexible wages and prices could get stuck in a position of involuntary unemployment; both sides accepted that it cannot. Instead, the debate shifted to a different set of questions: How long will it take for competitive markets to restore full employment? And is there a role for government intervention, through fiscal and or monetary policy, to speed up the process?

In Friedman's view, firms and households interacting in markets will quickly achieve an efficient allocation of resources. He did not take the extreme position that market participants are omniscient calculators with supernormal abilities to future prices. But he did accept Hayek's position (Hayek 1945) that the market system is an efficient information processor. At a point in time, market prices do a very good job of aggregating the information of hundreds of millions of market participants. And most importantly, governments cannot do better.

This position led Friedman to argue that the Federal Reserve Bank should follow a rule in which it maintained a constant growth rate of a monetary aggregate. If the Fed were to anticipate that the real economy would grow on average at a rate of $g=3 \%$, it should pick a money supply growth rate of $\Delta m=5 \%$. A policy of that kind, if successfully followed, would provide in Friedman's opinion, a monetary anchor. Inflation on average would equal $2 \%$; the difference between $\Delta m$ and $g$.

A money growth rule would not be expected to counteract the effects of uncertainty on employment and prices. But in Friedman's view, complete stabilization of the economy is both an unattainable and an undesirable objective. If the Federal Reserve Bank were to follow a money-targeting rule, in any given year the economy would deviate from the inflation target as a consequence of shocks to aggregate demand and to aggregate supply. But because government does not have an advantage at predicting future shocks over and above the private sector, it was Friedman's position that government should refrain from attempts to stabilize the real economy. Such attempts, in his view, would simply add additional sources of noise that make the job of private agents that much more difficult.

Friedman's policy of money-growth-rate targeting was tried in the period from 1979Q3, when Paul Volcker became Chair of the Federal Reserve System, to 1982Q4, when the policy was abandoned. ${ }^{10}$ During that brief interlude, money-growth-rate targeting led to a sharp drop in real output and a spike in unemployment. This was not the outcome that Volcker had hoped for and it led the Fed, in 1982Q4, to revert to interest rate control.

But although money-growth-rate targeting was abandoned, the application of a monetary rule was not. In the period from 1983Q1 through 2009Q1, the FOMC followed a rule in which it responded to both inflation and GDP by moving the money interest rate in a predictable way. John Taylor (Taylor 1993) has estimated the response of the money interest rate to the inflation rate and to the difference of real GDP from potential real GDP over the first part of this period and he has argued convincingly that the movement of the interest rate, carried out by the FOMC, is an example of the application of a successful monetary policy rule. I agree. By providing a predictable environment, the FOMC successfully managed the US economy. This, in my opinion, is a triumph of Friedman's argument for which he should be justly praised.

${ }^{10}$ Federal Reserve Bank of San Francisco (2003). 
But although I am a supporter of the position that the FOMC should behave in a predictable manner, I am not a supporter of Friedman's position that free markets, if left to themselves, will attain the best of all possible outcomes. I am not alone and it is widely accepted that intervention of some kind in markets is a desirable goal of public policy. A 1977 amendment to the Federal Reserve Act requires the Fed "to promote effectively the goals of maximum employment, stable prices, and moderate long-term interest rates." The question I seek to address here is: How can we best achieve the objectives?

I believe that the North-American Keynesians were wrong to concede the point that freemarket economies are self-correcting. It was a mistake to accept the argument that there is a unique configuration of money wages and money prices at which the labour market is in equilibrium. By providing an alternative account of labour market equilibrium, based on a theory of incomplete labour markets, I arrive in my own work at a very different account of the role of monetary and fiscal policy. I interpret search theory in a new and original way that provides a different micro-foundation to the Keynesian idea of involuntary unemployment. ${ }^{11}$

\section{What is Unemployment?}

The theory of general equilibrium was developed in continental Europe primarily by Léon Walras in Lausanne, Switzerland. To Keynes, who studied in Cambridge England with Alfred Marshall, Walrasian general equilibrium theory would have been regarded as "little more than an academic exercise in the counting of equations and unknowns", (Clower $1986 \mathrm{pp}$ 191). It was Hicks (Hicks 1937) who formulated The General Theory in Walrasian terms and who shaped the debate that followed as one of the consistency of underemployment equilibrium with market processes.

Once one formulates the question of unemployment in Walrasian terms, one has already conceded that the microeconomic concept of a 'market' makes sense as a description of the way that human beings find employment. In microeconomic theory, a collection of buyers meets a collection of sellers. Each side of the market chooses how much of a good to demand or to supply, taking the price at which the good can be exchanged parametrically. That vision may be a good description of rural agricultural markets; it is a rather poor description of the way that firms and workers contact each other in a modern capitalist economy.

To be clear, it is not just the price-taking assumption that is a poor description of the way that people find jobs in labour markets. Substituting a set of monopolistically competitive firms or a group of unions with the power to bargain over wages does not change the fact that the labour market is characterized predominantly by the fact that it takes time to identify who is a buyer and who is a seller of the particular type of labour that either side of the market seeks to transact. Each seller is a monopoly supplier of his own particular set of skills and each employer seeks, not just a warm body, but the specific warm body that best matches the needs of his particular enterprise. The labour market is not an auction market. It is a search market.

\section{The classical search model}

The introduction of an explicit theory of search to study labour markets appeared in economics at about the same time that Friedman was writing his presidential address. Dale Mortensen, writing in the celebrated volume, The Microfoundations of Employment and

\footnotetext{
${ }^{11}$ Farmer (2010a, 2010b, 2012a, 2016).
} 
Inflation Theory introduced a model of labour market search that led to the development of an entire branch of microeconomic theory culminating in the award of the Nobel Prize in Economics to Peter Diamond, Dale Mortensen and Chris Pissarides (DMP) in 2010 "for their analysis of markets with search frictions".

The key element of a search model is the matching technology (Diamond 1981), an explicit account of the costs incurred by a worker and a firm in the process of searching for each other. An omniscient social planner, if presented with the problem of filling a given number of free positions, would operate the matching technology to maximize social welfare.

There are costs and benefits of rapidly filling vacant positions. If vacant jobs are filled too quickly, society wastes resources by allocating too many people to the process of screening suitable workers and matching them with the correct job vacancies. The personnel involved in the screening process could more effectively have been allocated to the task of producing goods and services. If vacant jobs are filled too slowly, society wastes resources while idle people spend too much time between jobs.

The theory of unemployment that arises from search and matching models provides an explanation of what one might mean by the natural rate of unemployment. It is the rate that maximizes social output in the presence of screening costs as workers move from one job to another. But it does not provide a theory to explain why, in a free-market economy, the unemployment rate would be expected to be equal to the natural rate of unemployment. Quite the opposite.

By removing the Walrasian auctioneer and substituting a theory of random meetings between workers and firms, DMP provided a structure where Keynes' concept of multiple equilibrium unemployment rates emerges as a natural outcome. If firms and workers are price-takers, there are not enough relative prices in the DMP model to steer a market economy towards the correct allocation of resources. The DMP search model, when firms and workers are pricetakers, is under-determined.

To deal with the 'problem' of under-determination, DMP responded by adding a new equation. When a worker meets a firm, the worker will be willing to accept a job at any wage greater than or equal to his reservation wage. A firm will be willing to employ a worker for any wage less than or equal to his marginal product. There is an interval between the reservation wage and the marginal product that defines the set of all possible wages at which a firm and a worker would be willing to engage in trade. DMP chose one of these wages arbitrarily by defining a new parameter; the worker's relative bargaining weight. For example, if the bargaining weight is one half, the firm and the worker will agree on a wage that is halfway between the worker's reservation wage and his marginal product. I refer to a search model, closed in this way, as the classical search model.

The Keynesian Search Model

When Friedman introduced the concept of the natural rate of unemployment he defined it to be the equilibrium rate of unemployment that would prevail in an economy with search frictions. Here is Friedman on this point.

The "natural rate of unemployment", in other words, is the level that would be ground out by the Walrasian system of general equilibrium equations, provided there is imbedded in them the actual structural characteristics of the labor and commodity markets, including market imperfections, stochastic variability in 
demands and supplies, the cost of gathering information about job vacancies and labor availabilities, the costs of mobility, and so on. (Friedman 1968 page 8. My emphasis.)

The DMP model is an attempt to formalize this paragraph by constructing an explicit model of the labour market that incorporates "the actual structural characteristics of the labor and commodity markets". That attempt, in my view, is a spectacular failure. It fails because, once one adds a matching technology to the Walrasian model that explains how people meet, the price system is no longer capable of implementing the solution that would be chosen by an omniscient social planner. There is no longer an equivalence between the solution to a social planner's problem and the outcome achieved by competitive behaviour in markets.

In the Walrasian system a given distribution of wealth implies a particular social welfare function. It tells the social planner how much weight to give to the utility of each person in society. Different assumptions about how to weight each individual lead to different solutions to the social planning problem. But, for any given set of welfare weights, the solution to this problem is unique.

It is a remarkable feature of the formulation of market economies as conceived by Walras, that every equilibrium to the Walrasian system of general equilibrium equations is the solution to some social planning problem. Friedman's presidential address moves effortlessly between the two concepts of a competitive equilibrium and a social planning optimum. He assumes first, that an equilibrium that incorporates "the actual structural characteristics of the labor and commodity markets" will be unique. And second, he assumes that it will be optimal in the sense of Pareto: There is no intervention by government that can increase the welfare of one person without reducing the welfare of someone else.

In the implementation of Friedman's concept as it is embodied in the DMP model, both of these assumptions are manifestly false. In the absence of the new assumption, that when a firm meets a worker they bargain over the wage, the search model is under-determined. Once the model is closed by adding a new parameter, the relative bargaining weight of a worker, the equilibrium of the DMP model is no longer coincident with the solution to a social planning problem unless there is a happy coincidence between the bargaining weight of the worker and the characteristics of the matching technology. ${ }^{12}$

But why is that the natural way to close a search and matching model? In my own work I have developed a new branch of search theory in which I drop the assumption that firms and workers bargain over the wage and I assume instead that firms produce goods and services to meet aggregate demand. ${ }^{13}$ In my 2016 book, Prosperity For All, I refer for the first time to a search and matching model, closed in this way, as the Keynesian Search Model.

The Role of Financial Policy

In Hick's interpretation of the general theory as formulated in the IS-LM model, the markets for goods and the markets for assets are in equilibrium simultaneously.

The downward sloping line, labelled IS on Figure 2, represents all positions of the money interest rate and real GDP at which all of the goods produced in given period are willingly

\footnotetext{
12 The coincidence I refer to requires the bargaining power of the worker to equal the elasticity of the matching function (Hosios 1990 ).

13 I first presented these ideas at a 2006 conference in honour of Axel Leijonhufvud. The first published reference appears in Farmer (2008).
} 
purchased. The upward sloping curve, labelled LM on Figure 2, represents all combinations of the money interest rate and real GDP at which the demand for money, measured in units of goods, is equal to the money supply. In this reconciliation of the general theory with Walras, prices will eventually adjust to move the LM curve, the IS curve, or both, to the right until both curves intersect the vertical line labelled full employment real GDP.

I have formulated a different reconciliation of the general theory with Walras (Farmer 2012a, 2016) in which underemployment equilibrium may be a permanent feature of a free-market economy. If people persistently maintain pessimistic expectations of the value of their financial assets, there is no constellation of wages and prices capable of restoring fullemployment equilibrium. ${ }^{14}$ The 'problem' with Walras is not that prices are sticky, it is that that there are not enough relative prices to allocate correctly the search time of people between the activities of production and job search.

For most of the post-war period, the US unemployment rate has fluctuated within relatively narrow bounds. But it does not display a tendency to return to any natural rate of unemployment. Far from it; the behaviour of the unemployment rate is indistinguishable from a random walk. And at low frequencies, the unemployment rate moves very closely with the stock market (Farmer 2012b,2015). The low-frequency behaviour of the unemployment rate is ascribed by some economists to supply-side movements in the natural rate itself. ${ }^{15}$ That is a possibility, but one that I find unconvincing.

If the natural rate of unemployment is itself a random walk, the correlation between the stock market and the unemployment rate that characterizes the data could be understood in conventional terms. In the conventional view, rational forward-looking agents anticipate that the fundamentals of the labour market will be strong or weak and they adjust their perceptions of the value of financial assets accordingly. Under this explanation of the data, the stock market crash in November of 2008 occurred because rational forward-looking people correctly anticipated that a very bad fundamental event was around the corner. That seems unlikely.

A more convincing explanation is that the value that people place on financial assets is a selffulfilling prophecy that is influenced primarily by market psychology. ${ }^{16}$ When people feel rich they are willing to pay more on the expectation that they may realize a short-term gain. As people feel wealthier, they spend more and, as they spend more, firms employ more people to meet demand. If this explanation of the data is correct, it suggests a very different view of the role of governments in regulating the financial markets from that which has dominated political discourse for the past thirty years.

In my published work (Farmer 2013a, 2014) and in evidence to the U.K. Treasury Select Committee in 2013, I discussed the possibility that a new institution, similar to the central bank or the treasury, might achieve stability in the financial markets through the purchase

\footnotetext{
${ }^{14}$ In joint work with Konstantin Platonov, (Farmer and Platonov 2016) we have formulated a different version of the IS-LM diagram that we call the IS-LM-NAC model. Our version is supplemented by a third equation that we call the No-Arbitrage Condition (NAC). Unlike Hicks' ISLM model, our formulation of the general theory allows an under-employment equilibrium to occur not just in the short-run, but also in the long-run.

${ }^{15}$ See, for example, Gordon (2013).

16 The idea of implementing a rational-expectations equilibrium as a self-fulfilling prophecy first appeared in Azariadis (1981) and is developed further in Farmer (1993).
} 
and sale of treasury bills in exchange for direct government purchases of private equities. ${ }^{17}$ Financial stability is a separate objective from price level stability and it requires a different tool. By buying and selling treasury bills in exchange for money, the FOMC successfully stabilized the inflation rate for a period of nearly thirty years. By buying and selling treasury bills in exchange for equities, a sister institution to the central bank might hope to stabilize financial markets. The history of the connection of the financial markets to the real economy suggests that a policy of that kind would also help the Fed to achieve one of its currently mandated objectives: to maintain "maximum sustainable employment".

\section{Conclusion}

Economics is a science. But it is not an experimental science and because we cannot easily confront our ideas with the light of experimental truth, we frequently follow paths that lead us down blind alleys. The General Theory of Employment Interest and Money was not a wrinkle on the Quantity Theory of Money. It was a triumph of rational thought which altered economics, politics and popular thinking forever. To answer the question that Franco Modigliani posed to the attendees of a 1977 conference at the Federal Reserve Bank of San Francisco: Should we Forsake Stabilization Policy? My answer is: Not if we wish to maintain "maximum sustainable employment". But the reason is not that wages and prices are slow to adjust: it is that market economies can often get stuck in an equilibrium that is not socially optimal.

${ }^{17}$ Farmer (2013b, 2013c). 


\section{References}

Azariadis, Costas, (1981). "Self-fulfilling Prophecies," Journal of Economic Theory, 25(3): 380-396.

Clower, Robert W. (1986) "Reflections on the Keynesian Perplex", in Money and Markets, Essays by Robert W. Clower, Donald A. Walker, ed. Cambridge University Press, Cambridge U.K.

Diamond, Peter A. (1981). "Mobility Costs, Frictional Unemployment, and Efficiency." Journal of Political Economy, 89(4): 798-812.

Farmer, Roger E. A. (1993). The Macroeconomics of Self-Fulfilling Prophecies, MIT Press, Boston MA, 1st edition 1993

Farmer, Roger E. A. (2008). "Aggregate Demand and Supply", International Journal of Economic Theory", vol. 4, pp 77-93, 2008

Farmer, Roger E. A. (2010a). “How to Reduce Unemployment: A New Policy Proposal". Journal of Monetary Economics: Carnegie Rochester Conference Issue, 57(5) 2010.

Farmer, Roger E. A. (2010b). Expectations Employment and Prices Oxford, Oxford University Press.

Farmer, Roger E. A. (2012a). "Confidence Crashes and Animal Spirits." Economic Journal, 122: 155-172

Farmer, Roger E. A. (2012b). "The Stock Market Crash of 2008 Caused the Great Recession: Theory and Evidence", Journal of Economic Dynamics and Control , 36: 696-707, (Plenary Address to the Society for Computational Economics: Federal Reserve Bank of San Francisco, summer 2011)

Farmer, Roger E. A. (2013a). "Qualitative easing: a new tool for the stabilization of financial markets: The John Flemming Memorial Lecture". Bank of England Quarterly Bulletin, December Q4:405-413

Farmer, Roger E. A. (2013b). “Quantitative Easing”, Written Evidence to the Treasury Committee of the U.K. Parliament, Session 2102-13. Oral evidence presented, 24th, April 2013

Farmer, Roger E. A. (2013c). "Supplementary Written Evidence", published by the Treasury Committee

Farmer, Roger E. A. (2014). "Financial Stability and the Role of the Financial Policy Committee." The Manchester School, 82 S1, pages 35-43, 2014

Farmer, Roger E. A. (2015). "The Stock Market Crash Really Did Cause the Great Recession", Oxford Bulletin of Economics and Statistics, 77(5): 617-633

Farmer, Roger E. A. (2016). Prosperity for All: How to Prevent Financial Crises, Oxford, Oxford University Press

Farmer, Roger E. A. and Konstantin Platonov (2016). "Animal Spirits in a Monetary Model". CEPR DP 11197, March 2016, NBER working paper 22136 
Federal Reserve Bank of San Francisco (2003). "How did the Fed change its approach to monetary policy in the late 1970s and early 1980s?" Dr. Econ, https://www.frbsf.org/education/publications/doctorecon/2003/january/monetary-policy-1970s-1980s/ Retrieved March 25 2018.

Friedman, Milton (1968). "The Role of Monetary Policy", American Economic Review 58(1): $1-17$

Friedman, Milton and Anna Jacobson Schwartz (1963). A Monetary History of the United States, 1867-1960, Princeton: Princeton University Press for NBER.

Gordon, Robert (2013). "The Phillips Curve is Alive and Well: Inflation and the NAIRU During the Slow Recovery", NBER WP 19390.

Hayek, Friedrich A. (1945). "The Use of Knowledge in Society", The American Economic Review, 35(4): 519-530.

Hetzel, Robert L. and Ralph F. Leach (2001) "After the Accord: Reminiscences on the Birth of the Modern Fed.", Federal Reserve Bank of Richmond Economic Quarterly Volume 87/1 Winter, pp 57-64.

Hosios, Arthur (1990), On the Efficiency of Matching and Related Models of Search and Unemployment, Review of Economic Studies, 57: 279-98.

Hume, David (1742). "Of Money", in Essays, Moral, Political and Literary, Indianapolis IN, Liberty Fund Inc. 1987

http://www.econlib.org/library/LFBooks/Hume/hmMPL26.html retrieved March 25th 2018.

Modigliani, Franco (1977), Franco Modigliani, 1977. "The monetarist controversy; or, should we forsake stabilization policies?," Economic Review, Federal Reserve Bank of San Francisco, issue Spring Supplement: 27-46.

Mortensen, Dale T. (1970). "A Theory of Wage and Employment Dynamics," in Microeconomic Foundations of Employment and Inflation Theory. E. S. Phelps et al., eds. New York: W. W. Norton.

Radcliffe Committee (1959). "Committee on the Working of the Monetary System, 19571959," The National Archives, Kew.

Phelps, Edmund S. et. al. (1970) Microeconomic Foundations of Employment and Inflation Theory, W.W. Norton and co. New York

Taylor, Jon B. (1993). "Discretion Versus Policy Rules in Practice", Carnegie-Rochester Conference Series on Public Policy 39: 195-214 